\title{
Witkacy i antybinarna teoria tekstu
}

Ilekroć zaczynam pisać o Witkacym, przychodzi mi na myśl słynne zdanie Konstantego Puzyny, że artysta wyżywi jeszcze niejedno pokolenie witkacologów. I oto stale tak się dzieje - Witkacy wciąż jest młody i modny.

Problem, który stwarzają nowe interpretacje dawnych (zwłaszcza wybitnych) pisarzy, polega dziś na tym, że został odwrócony porządek eksponujący prekursorski charakter tekstów. Pojmowanie dzieła sztuki jako gotowego, danego w określonym kształcie przedmiotu utrwalało przekonanie, że interpretator wyczytuje z nich nowe sensy, które odsłaniają mu się z materii przedstawionego tekstu. To dzieła Słowackiego, Gombrowicza, Witkacego, Schulza pokazywały oryginalność, bo „wyprzedzały epokę". To Oni byli nowatorami, a my odkrywaliśmy nagle, że np. Gombrowicz chciał być pierwszym strukturalistą (!) i nie mógł przewidzieć, że wkrótce zostanie pierwszym postmodernistą. Czymże w historii stawał się już nieraz Witkacy? Odczytywany przez modernizm, strukturalizm, psychoanalizę, łączony $\mathrm{z}$ teatrem absurdu, wpadł też w sidła postmodernistów, nie umknął dekonstrukcji, i - jak się wydaje nie oprze się dziś ani performance'owi (porzuci szaty dandysa dla stroju performera), ani performatyce (dzięki której uzyska możliwość zniesienia wielu dylematów swoich teorii).

Ważne jest to, że wciąż chcemy mówić Witkacym! Problem nie leży zatem w prekursorstwie, ale w rekontekstualizacji. Zmiana języka opisu i kontekstu, w którym odczytywane jest dzieło artysty sprawia, że pisarze wydają się wciąż na nowo budować swoje niedokończone projekty, a my, przykładając nasz ogląd do ich spojrzenia, sprawiamy, że żywimy się sobą nawzajem.

Dlatego tak ważna wydaje się kategoria spojrzenia. Jak można sądzić doświadczenie wizualne ma charakter performatywny. Spojrzenie nas wyraża, ale i przekształca poznawany obiekt, stwarzając go dla nas od nowa, kreuje raz jeszcze od początku i nas, i siebie. Spojrzenie wyznacza przestrzeń, czyni zdarzenie, powołuje byty. Oddaje nam świat i równocześnie pokazuje nas światu. Witkacy rozumiał spojrzenie. Jego twórczość musiała łączyć wizualne ze słownym, obejmować razem obraz i słowo, realizować malarstwo, przyglądając się muzyce, bo tylko taki mariaż dawał możliwość stwarzania interakcji, pokazania tego, co płynne, niestabilne, przejściowe, migotliwe w grze sensu, niepewne w ukonstytuowaniu, niejednoznaczne $\mathrm{w}$ znaczeniu, rozgrywane między patrzą- 
cym a bytem. Patrzymy na Witkacego, mając stale wrażenie, że on wciąż patrzy na nas: podkreśla dystans, prowokuje, stawia widza w obliczu strojenia min i grymasów na zdjęciu, spogląda z odbicia zwielokrotnionego w lustrze, jego spojrzenie wyziera $\mathrm{z}$ obrazu innej osoby, która paradoksalnie utrwala jego własne gesty, wypełniając marginesy czytanych książek, kieruje wzrok równocześnie zarówno ku tekstowi, jak i zwrotnie ku sobie, powołując performatywnie „scenę czytania teorii” na oczach potencjalnych „czytelników jego czytania”.

W tych spojrzeniach Witkacy jest dramatyczny, patrząc, łączy różne rzeczy, zlewa odmienne istnienia w jedna postać, stara się spojrzeć zawsze $\mathrm{z}$ boku, jakby skrzywiony, zdeformowany poprzez przyjęty kąt patrzenia obraz miał zaraz ujawnić nam inną od przyjętej w powszechnych sądach, rację bytu.

Spojrzenia Witkacego zawsze poruszały przestrzeń, czas, pojęcia, zawsze wiązały się z działaniem.

Witkacy znosi antynomie, łączy sprzeczności, zestawia wykluczenia. Dla niego ważne są pojęcia zaprzeczone „wiedza o niewiedzy”. Parodiował język i myślenie w kategoriach systemów filozoficznych, np. fenomenologii: „Świat bezgłośnie i bezruchowo zachybotał się w zawiasach swych"1. "Chybotał się świat, chybotał, a nie chciał się przechybotać na drugą stronę całkowitego zrozumienia"2. Chciałoby się dziś powiedzieć, że Witkacy nie może dokończyć akcji ze światem, który chybotliwy i chwiejny $\mathrm{w}$ swych przejawach, niejednoznaczny i niezrozumiały do końca, nigdy nie „przechybota” się na drugą stronę zrozumienia. Epistemologia Witkacego ma zatem swoistą dynamikę - jest prowokacją, porusza rzeczy, by w ruchu nie zastygały i nie dały się uchwycić do konca. Wieczna zmienność i niejednoznaczność rzeczywistości niepokoi, ale i zachwyca.

Ciało tekstu nie może być wręcz odczytane poza ciałem osoby. Pomaga opisać to zjawisko kategoria już nie tylko aktora, ale performera, który zaciera gdzieś gesty sztuki i autentyzmu doświadczania zmysłowego, bioestetyki czy ujęcia estetyki nakierowanej antropologicznie. Witkacy, doświadczając sztuki, poznaje siebie, wychodząc od swego ,ja”, dokonuje przewartościowań w sztuce.

Myślę stale o tym, co takiego w twórczości Witkacego zdecydowało, że stał się aż tak bliski współczesności. Uznałabym Go za twórcę antybinarnej teorii tekstu. Antybinarna estetyka jest u Witkacego czytelna w różnych ujęciach i wymiarach.

${ }^{1}$ S.I. Witkiewicz, Jedyne wyjście, oprac. A. Micińska, Warszawa 1993, s. 56.

2 Tamże, s. 57. 
Kategorie antybinarne, transgresyjne i transwersalne przystają idealnie do twórczości artysty (por. Mandelbaumy, kobietony itp.). Antybinaryzm towarzyszy, moim zdaniem, współczesnym nurtom filozofii. Oznacza wyrwanie się z odgraniczania, zobaczenie samych granic, obszarów liminalnych (Turner), krawędzi, szwów, marginesów, śladów (Derrida), pochwały niekonsekwencji (Kołakowski), figury chiazmu (de Man). Witkacy idzie tą drogą.

Myślał o stworzeniu systemu, np. Estetyki Ogólnej, polegającym na całościowym ujęciu sztuki różnych kierunków, „teorię sztuki tak dawnej, jak i nowej w jednolitym ujęciu”, stawiał pytanie o status estetyki (czy filozofia, czy teoria sztuki). Dziś sądy Witkacego nie mogłyby być bez zastrzeżeń przyjęte, zresztą sam Mistrz miał do pojęcia systemu spory dystans, co wyrażał humorystycznie „system is system trzeba skończyć by z tem". Praktyka przeszkadzała sztywnej teorii, nic się nie zgadzało, materia artystyczna stawiała opór, sprawiając, że wszystko pękało, pojawiały się szwy, niedokończenia, urwania w pół aktu itp. symptomy niedoskonałości. Witkacemu nie udało się stworzyć poetyki normatywnej. Jego dzieło (czyli traktowane łącznie, przenikające się wzajemnie, teksty artystyczne i teoretyczne) jest więc wypowiedzią o tym, ,jak się nie udaje" i o tym, ,jak się próbuje" i o tym także, ,jak powstają pęknięcia". Witkacy w sferze artystycznej dokonał teoretycznej wypowiedzi o niemożności stworzenia systemu, o chaosie, który przynosi niekiedy antybinarne u podstaw scalenie (jedność $\mathrm{w}$ wielości), o niedoskonałości i złudzie, które przynoszą pustkę, o braku odpowiedzi (nienasycenie).

Układając numer „Przestrzeni Teorii” poświęcony Witkacemu, przyszło mi na myśl, że był on zawsze twórcą, który łączył i wręcz eliminował sprzeczności. Witkacym mówimy wszyscy, poprzez pokolenia.

Pisząc o dawnych twórcach, nie sposób pominąć serii interpretacji narosłych wokół artystów przez lata. Spojrzenie wstecz sprawia, że wyłaniają się z przeszłości także interpretacje naszych dawnych Mistrzów. Funkcjonujące już jako klasyczne, odczytywane dziś raz jeszcze, równolegle do czasu aktualnej lektury, oglądane naszymi oczami, ożywają na nowo. To my nie dajemy tym interpretacjom sklasycznieć, wyczytując z nich własne nastroje i myśli, obawy i refleksje, nadzieje i rozczarowania. Czytając Witkacego, obejmujemy lekturą także głosy wybrzmiałe, teksty - wydawałoby się doczytane do końca - interpretatorów pisarza, ale i one nagle ożywają znowu, w innym czasie, w odmiennej przestrzeni, otwierając się na nas w polu nowej współobecności.

W tym numerze „Przestrzeni Teorii” w dziale Pamięć przypomnieć chcielibyśmy poprzez teksty o Witkacym postać Profesora Jerzego Ziomka, od którego śmierci mija właśnie 20 lat. 
Chciałabym ten numer dedykować mojemu Mistrzowi, Artyście słowa i Twórcy przestrzeni niejednej teorii. Profesor Ziomek Witkacego lubił i cenił. Pamiętam zebrania ówczesnego Zakładu Teorii Literatury, kierowanego przez Profesora, które poświęcone były właśnie Witkacemu. Słyszę jeszcze i dziś głos Profesora opowiadającego o artyście z Zakopanego. Przestrzeń teorii nie znosi pustki i milczenia, stale dopomina się głosu - nawet wobec dramatu śmierci nie chce pozostać niema. Myślę, że zamiast echa naszych wspomnień, niech mówią wprost pozostawione teksty Profesora, poprzez które wciąż umiemy rozmawiać o personalnym dossier Witkacego.

Anna Krajewska 